Potryvaieva Natalia, Doctor of Economics, Professor of the Department of Accounting and Taxation, Mykolayiv National Agrarian University, Mykolayiv, Ukraine

ORCID ID: 0000-0002-9781-6529

e-mail: potrivaeva@mnau.edu.ua

Pelypkanych Inha, Postgraduate, Mykolayiv National Agrarian University, Mykolayiv, Ukraine

ORCID ID: 0000-0001-8798-3086

e-mail: pelipkanich@mnau.edu.ua

Potryvaieva Oleksandra, Applicant for higher education, Mykolayiv National Agrarian University, Mykolayiv, Ukraine

\title{
Effective Investment Decision for Fixed Assets Management
}

Abstract. Introduction. Constant changes in economic and political situation create more stringent conditions for the survival of modern businesses while requiring effective management of the enterprise's life cycle and also investing in a simple and expanded reproduction of fixed assets. An enterprise like any socio-economic organism needs constant development, growth and renewal, only these conditions ensure its competitiveness. Theoretical and methodological aspects of selection and evaluation of the investment decisions' efficiency are constantly the focus of scientific world attention. However, it should be noted, the issues of choosing the most rational ways and stages of making an effective investment decision to manage the reproduction of fixed assets of the enterprise are not thoroughly studied, thus, they need further efforts to develop new proposals to improve their quality and prevent possible risks.

Purpose. The purpose of the article is to study the factors and stages of making the appropriate investment decision to reproduce fixed assets with efficient use of resources.

Results. The aspects of effective investment decision making for reproduction of fixed assets management are researched. It is proved that the attraction of sources of financing investment decisions is influenced by objective and subjective factors. The stages of making an investment decision in order to select the optimal sources of financing of the investment project are substantiated. It is found that the decision on the reproduction of the enterprise's fixed assets should be comprehensive and aimed at both tangible and intangible components.

Conclusions. Use of managerial approach in the process of reproduction of fixed assets investment lets making effective investment decision, which is implemented through some stages with appropriate methodological support. Taking into account the objective and subjective factors influencing the efficiency of the investment decision will help to avoid difficulties in managing the reproduction of fixed assets in the long run. The choice of financing source for an investment project is the most important management decision. The decision to reproduce the fixed assets of the enterprise should be comprehensive and aimed at both tangible and intangible components. The managerial decision may be considered as effective if it is directed to achieve the resource efficiency, obtained as a result of development and implementation of the investment decisions, where financial and material investments, qualified personnel, etc. can act as resources. This requires making and implementation of such decisions by qualified managers provided that the sequence of the stages would be followed, including collection of information, decision-making and ensuring effective implementation of the investment decision.

Keywords: fixed assets; investment; reproduction; efficiency; management.

УдК 658.2:005.93:658.152

Потриваєва Н. В. доктор економічних наук, професор, професор кафедри обліку і оподаткування, Миколаївський національний аграрний університет, м. Миколаїв, Україна

Пелипканич I. В., аспірант, Миколаївський національний аграрний університет, м. Миколаїв, Україна

Потриваєва О. І., здобувач вищої освіти, Миколаївський національний аграрний університет, м. Миколаїв, Україна

\section{Ефективне інвестиційне рішення щодо управління відтворенням основних засобів}

Анотація. Постійна зміна економічної та політичної ситуації створює жорсткіші умови виживання сучасних суб'єктів господарювання, вимагаючи при цьому наявності ефективного управління життєвим циклом підприємства, простого і розширеного відтворення основних фондів. Підприємство як будь-який соціально-економічний організм потребує постійного розвитку, зростання та оновлення, тільки в цьому випадку забезпечується його конкурентоспроможність. Теоретичні та методологічні аспекти відбору та оцінки ефективності інвестиційних рішень знаходяться постійно у центрі уваги наукового світу. Зазначено, що питання вибору найбільш раціональних шляхів та етапів прийняття ефективного інвестиційного рішення щодо управління відтворенням основних засобів 
підприємства досліджені недостатньо, тому потребують подальших зусиль за напрямом розроблення нових пропозицій щодо підвищення їх якості та попередження можливих ризиків.

Мета статті полягає у дослідженні факторів та етапів прийняття відповідного інвестиційного рішення задля відтворення основних засобів з ефективним використанням ресурсів.

Досліджено аспекти прийняття ефективного інвестиційного рішення щодо управління відтворенням основних фондів підприємства. Доведено, що залучення джерел фінансування інвестиційних рішень відбувається під впливом об'єктивних і суб'єктивних факторів. Обгрунтовано етапи прийняття інвестиційного рішення з метою вибору оптимальних джерел фінансування інвестиційного проєкту. Встановлено, що рішення щодо відтворення основних фондів підприємства повинно бути комплексним й спрямовуватися як на матеріальну, так $i$ на нематеріальну їх складову.

Застосування управлінського підходу у процесі інвестування відтворення основних фондів підприємства дозволяє прийняти ефективне інвестиційне рішення, що відбувається у декілька етапів з відповідним методичним забезпеченням. Врахування об'єктивних та суб'єктивних факторів впливу на ефективність інвестиційного рішення сприятиме уникненню складнощів в управлінні відтворенням основних фондів на довгостроковий період. Вибір джерела фінансування інвестиційного проєкту є найбільш важливим управлінським рішенням. Управлінське рішення вважсається ефективним у разі спрямування його на досягнення ресурсної результативності, отриманої за підсумками розробки і реалізації інвестиційних рішень, де в якості ресурсів можуть виступати фінансово-матеріальні вкладення, кваліфікований персонал тощо. Саме для цього потрібне прийняття і реалізація даних рішень кваліфікованими кадрами за умови дотримання послідовності етапів, включаючи збір інформації, ухвалення рішення та забезпечення ефективного виконання інвестиційного рішення.

Ключові слова: основні фонди, інвестиції, відтворення, ефективність, управління.

Setting of the problem. Constant changes in economic and political situation create more stringent conditions for the survival of modern businesses while requiring effective management of the enterprise's life cycle and also investing in a simple and expanded reproduction of fixed assets. An enterprise like any socio-economic organism needs constant development, growth and renewal, only these conditions ensure its competitiveness.

Analysis of recent research and publications. The questions connected to the methods of investment decision formation were considered in the works of such researchers as O. Burban, H. Haidai, V. Klochan, A. Kozlovskyi, A. Kravchun, O. Malykhina, I. Marekha, O. Novikov, N. Sirenko, V. Shebanin, etc.

For example, H. Haidai considers that the development of the enterprises' of investment activity strategy depends directly on the investment potential, which creates possibilities to determine the priority areas of investment activity for the long term within time horizons with an acceptable probability [2]. Marekha I. concentrates his attention on the evaluation of investment quality when substantiating the investment decisions [7]. A group of researchers led by O. Malykhina deepens the understanding of the effectiveness of management accounting system and budgeting in the development and realization of the investment decision, determining the main stages of its implementation [6]. A. Kozlovskyi considers decision-making tools for the implementation of the investment project. The author systemizes the approaches to evaluation of the investment risks and making an informed management decision [4]. N. Sirenko and K. Mykuliak by the research of the indicators of investment support for the development of the agricultural sector and their rationalization adopt increasing the potential of funding sources for modernization of production and diversification of agricultural enterprises [11]. Burban O. and I. Kryvovjaziuk reveal an integration approach to identifying the impact of the external environment on the effectiveness of investment decisions [1]. V. Shebanin, O. Novikov and M. Karpenko substantiate expediency of investing resources in the introduction of sprinkler irrigation of land in agricultural enterprises by the results of the calculations of capital investments performed [12]. The development of an enterprise based on the built economic model and the criteria of agricultural production optimization are determined by N. Sprynchuk, I. Voronetska, H. Korniichuk, and $O$. Kravchuk [13].

Therefore, theoretical and methodological aspects of selection and evaluation of the investment decisions' efficiency are constantly the focus of scientific world attention. However, it should be noted, the issues of choosing the most rational ways and stages of making an effective investment decision to manage the reproduction of fixed assets of the enterprise are studied insufficiently, thus, they need further efforts to develop new proposals to improve their quality and prevent possible risks.

The purpose of the article is to study the factors and stages of making the appropriate investment decision to reproduce fixed assets with efficient use of resources.

Statement of major material. In modern world the management of an enterprise may be efficient only if the principles established in accordance with the laws of social reproduction are a reflection of the internal relationships and interdependencies of the system. The complex of economic relations arising in the process of production, distribution exchange and consumption influences the whole process of reproduction contributing to the goals of the social system.

Each production process assumes the presence of interacting elements - labor resources and means of production (means and objects of labor). The basis of the means of labor of economic entities are fixed assets (capital, materialized in buildings, structures, machines, equipment, operating in the production process for a significant period of time, which serves several production cycles). Thus, in the managerial approach to the issue of 
the reproduction process the simple fixed assets reproduction means restoring their usefulness (productivity, cost of production) to the initial level, that is, at the time of purchase, moreover, there is no significant increase in the value of fixed assets; expanded reproduction of fixed assets is an increase in their usefulness through modernization, to a level higher than the initial one (at the time of purchase), in particular.

The outlined types of fixed assets of the enterprise reproduction are effective for various degrees of their wear, but expanded reproduction of fixed assets is possible provided their simple reproduction. The initial process of investing in the reproduction of the enterprise's fixed assets within the management approach is based on making an effective investment decision, conducted in several stages, each of which has its own basis of effective methodological support (Fig.). However, in order the constant and orderly development of the system to take place and the process of reproduction to be subject to effective management providing achievement of the set goals, it is necessary to influence the control levers of the system and the process of reproduction which are investment processes in reproduction of the enterprise's fixed assets, so making effective investment decisions is necessary.

Let's note, that in the general sense a decision is considered as a conscious and volitional act, both at the level of the person and the business entity, which provides a choice between alternative options for possible behavior in the process of achieving a specific goal [5]. An investment decision is characterized by such basic features, as 1) focus on long-term benefits; 2) strategic nature, which is manifested in the long term implementation; 3) a significant level of costs, accompanied by corresponding risks [1].

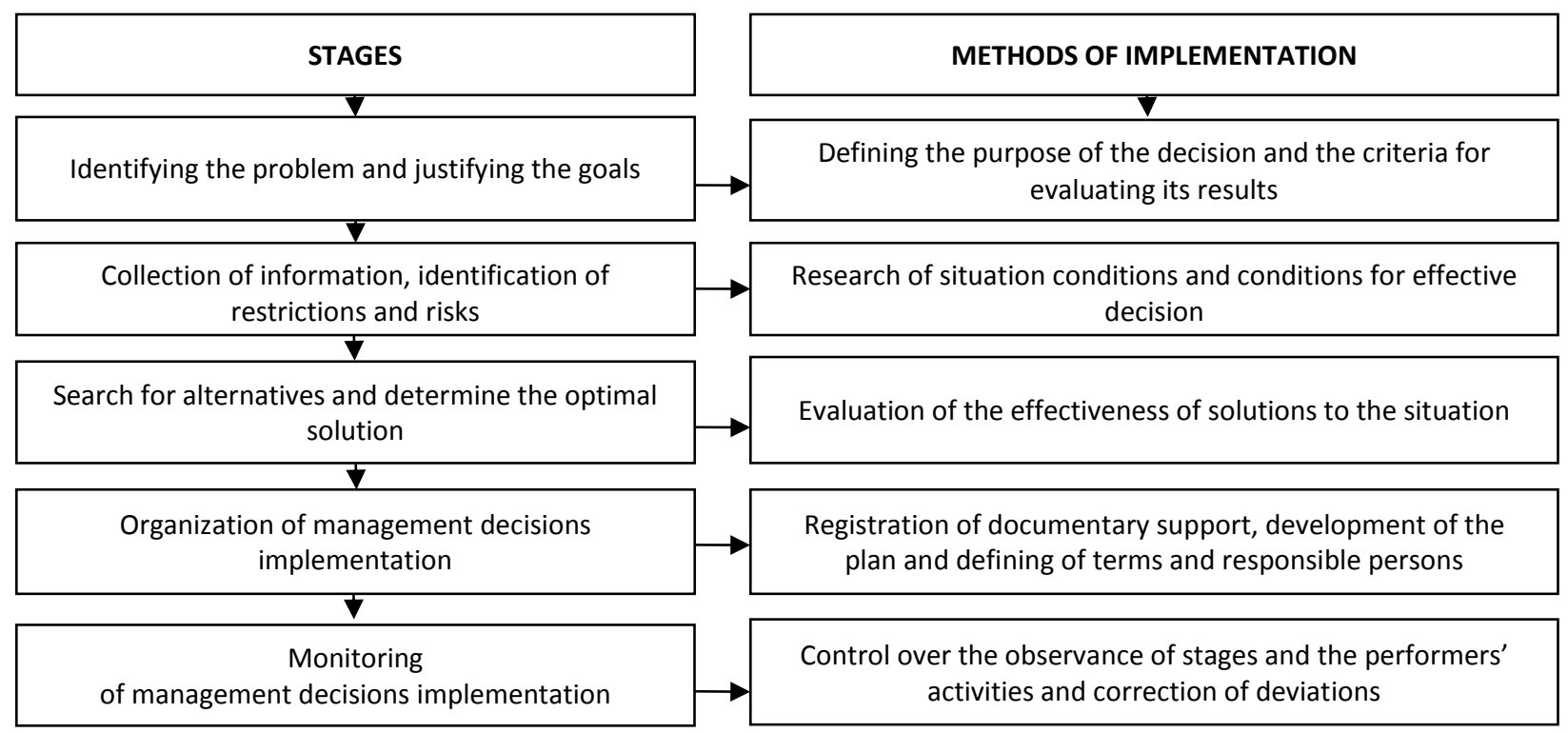

Figure - Stages of development and implementation of an effective management decision and methods of its provision

Source: with use [14]

Depreciation payments, part of funds from the company's own profit and quite rarely the funds allocated by the state are traditionally used for management in domestic economy; moreover, these elements are in this case source of funding for investment decisions to manage the reproduction of fixed assets. In other words, it is necessary to search for sufficient amounts of financial investments when developing management schemes. But there is a situation now, when not only particular agrarian enterprise buys the whole agricultural industry is not invested in the required amount.

As practice shows, low investment attractiveness leads to difficulties in managing the reproduction of fixed assets of enterprises, depreciating potential opportunities from the use of these sources of financing investment decisions, and accordingly these decisions themselves. These problems arise under the influence of the following major factors that affect the efficiency of the investment decision.

Regarding the management of fixed assets reproduction, namely: objective ones, which do not depend on the management of enterprises, and subjective ones, the solution of which is possible within the enterprise.

In our opinion, the objective factors include the imperfection of the legislation on investment activities, including certain aspects of banking and tax legislation. For example, our banks are quite cautious and limited in lending to investment projects of agricultural enterprises due to high investment risks.

The possibilities of enterprises to carry on investment projects, to use profit and depreciation to finance investment projects are significantly limited. Nowadays the production equipment of agricultural enterprises is 
highly worn (about 70\%), the production volume is low (comparing to 1990, the production volume has decreased more than thrice), and also working capital is scarce. In turn, about $40 \%$ of industrial enterprises are unprofitable. Therefore, economic entities do not have the opportunity to use depreciation and profit to finance investment projects. The unfavorable investment climate was formed as a result of low investment attractiveness and investment activity and is a combination of their factors. The investment climate has "highlighted" the investment priorities of the industry [1].

Thus, in order to ensure effective investment management of reproduction of the enterprise fixed assets in the long run, it is necessary to increase the investment attractiveness of the agricultural sector itself, which requires state assistance. The main step in this direction is to create more perfect and transparent rules of investment activity.

In our opinion, the only way out of this situation, is the focus on the regulation of subjective factors due to the inability of most agricultural enterprises to intensify the use of investment resources.

We consider such factors as the lack of high-quality specialists in the field of management at different levels; wrong choice of sources of financing investment decisions; not following the rules of step-by-step going through the making investment decision, etc., should be included as the main subjective factors.

Making and implementation of an effective investment decision require the presence of professional staff, lack of which endangers the implementation of basic tasks or leads to unnecessary overruns of precious resources. As managers make investment decisions, and particular employees implement them in the field, violation of one of the links in the chain, his incompetence will simply lead to the displacement of the enterprise from the market by competitors, who have more qualified staff.

There are two major ways of involvement of professionals to work for an organization: training of own professionals or involving the professionals of the competitors. The need to use the experience of professionals, in particular, is due to the fact that the manager was able to determine the optimal sources of financing investment decisions.

In our opinion, the structure of sources of financing of investment decisions in the management of simple and expanded reproduction of fixed assets by the types of reproduction organized at modern enterprises requires usage of depreciation and partly of own funds of the enterprise in the form of incomes obtained from its main activities as the source of financing the simple reproduction of fixed assets. In modern conditions, the sources of financing the expanded reproduction of fixed assets is leasing, net profit in the part, which was not paid to the owner in the form of dividends, long-term bank loans or funds received from the issue of securities (shares and bonds), targeted financing, as well as partial savings from the depreciation fund of the enterprise [10].
Depreciation distribution into the expanded reproduction of fixed assets is due to the specifics of its assessment and expenditures: it is assessed throughout the regulatory life of fixed assets, and the need for its spending arises only after its actual disposal, so the assessed depreciation may be used as an additional source of financing of the investment decision for expanded reproduction till the moment of its replacement from operation of worn-out fixed assets. In addition, the use of depreciation on the expanded reproduction contributes to scientific and technological progress; as a result, some types of fixed assets may become cheaper: more perfect and more productive cars and the equipment are put into operation. Therefore, taking into account the goals of the enterprise for a simple and expanded reproduction of fixed assets, it is necessary to determine the optimal sources of financing the investment decision.

In our opinion, the initial choice of the source of financing of the investment decision both for expanded and for simple reproduction is the most important management decision. But it is not enough to determine the optimal sources of financing investment decisions, it is necessary to provide an effective investment decision in the process of their use, for what this decision should be made respecting the stages of its implementation.

The experience of the best and successful domestic and foreign enterprises persuades that making investment decision can be implemented step-by-step, namely: 1 ) collection of information; 2 ) decision making; 3) ensuring the implementation of the decision.

At the first stage of investment decision making the most labor-intensive part of work takes place, when the professionals determine which department of the organization needs the financing of the fixed assets reproduction.

The large-scale work on collection of information, comparing the situation with the pre-planned one and the final determination of the direction of investing into reproduction of the enterprise's fixed assets is performed during the stage of forming the problem. In this case, the accuracy of the information collected has the primary importance as it will influence on the final decision of investing.

The second stage includes the very creation of investing and reproducible models, determination of alternative investment decision and chooses of a decision or decisions necessary to realize. The solution to this problem is performed with the help of the assessment of efficiency of alternative investment decisions:

methods of multicriteria choose of alternatives;

methods of decision making in conditions of risk and uncertainty, which is through the system of criteria providing different level of risk, the consequences of such decision are evaluated.

The final stage of decision making on investing of reproduction of fixed assets is, as a rule, is the most difficult to realize. This stage involves two important and 
interdependent components of provision the realization of the investment decision: financial and administrative.

Administrative support for the implementation of the investment decision is the reflection of managerial will manifested, for example, through signed orders of other administrative documents.

Financial support includes sufficient assets to implement the investment decision in practice. A threat to the reproduction of fixed assets may be hidden in the part of financial support as this part of the third stage of decision making isn't implemented completely, or even isn't implemented at all. In other words, enterprises try to save on the reproduction of fixed assets, and such approach to investment decision making will make them completely non-competitive in future, even under the modern approach to management. In case when the decision to invest in the reproduction of fixed assets of the enterprise is still made, we consider the reproduction should be complex, namely, it doesn't make any sense to invest into the reproduction of the enterprise's fixed assets without relevant investment into intangible part of productive capacities.

The evaluation of current state of investment projects' implementation in the agro-industrial complex proves preparation and implementation of 444 investment projects (as of July 1, 2019) with a total value of over UAH 40.6 billion, which is 51 projects and UAH 0.5 billion more the corresponding period of 2018. The own funds of the enterprises in the agro-industrial complex remain the major source of financing- $72.8 \%$. The largest number of investment projects are implemented in Cherkasy (54), Vinnytsia (52), Poltava (51), Lviv (47), Kherson (30), Mykolayiv (27), Zhytomyr (22) and Kyiv (22) regions. The cost of the investment projects fluctuates from UAH 100 thousand to 9.6 billion [3].

It should be noted, that in practice, insufficient funds are spent not only on the problems of investing in reproduction of fixed assets in industry and agriculture, but they are allocated into one tangible or intangible component of fixed assets, as there is no complex approach to solving the whole problem. Unfortunately, the demand for investments in Ukrainian economics exceeds their supply significantly, and this results into their high costs in market conditions. Thus, the loan investments (bank, commercial loans, leasing) are mostly unfavorable for agriculture now, as they are mostly shortterm and too expensive. According to the limits of inner resources, foreign investments may be the most attractive source of resource provision in agriculture. However, the lack of viable production mechanisms along with the low level of liquidity of most enterprises in the agricultural sector creates significant obstacles to them.

In our opinion, creation of joint-ventures should be considered as the major direction of Ukrainian agroindustrial complex integration into the world economy. It would give the possibility to raise foreign capital more intensively and to strengthen the regional economy significantly. It would be reasonable to make an example of the successful activities of NIBULON Ltd. JV in the field of creation of the most modern truck fleet in Ukraine due to effective investment decision on purchasing of new German and Swedish trucks. We consider it the example of effective investment into agricultural production. The large-scale investment program implementation became possible for NIBULON Ltd. JV due to cooperation with major European financial organizations, i.e. European Investment Bank, International Finance Corporation and European Bank for Reconstruction and Development [8]. The use of new equipment will help to reduce the damage of the roads, to save fuel and lubricants and, the most important, to preserve the ecology of the environment. Therefore, the effective investment decision making is the most important condition for reproduction of fixed assets management. And it is aimed to carry out the particular assigned tasks.

Conclusions. Use of managerial approach in the process of reproduction of fixed assets investment lets making effective investment decision, which is implemented through some stages with appropriate methodological support. Taking into account the objective and subjective factors influencing the efficiency of the investment decision will help to avoid difficulties in managing the reproduction of fixed assets in the long run. The choice of financing source for an investment project is the most important management decision.

The decision to reproduce the fixed assets of the enterprise should be comprehensive and aimed at both tangible and intangible components. The managerial decision may be considered as effective if it is directed to achieve the resource efficiency, obtained as a result of development and implementation of the investment decisions, where financial and material investments, qualified personnel, etc. can act as resources. This requires making and implementation of such decisions by qualified managers provided that the sequence of the stages would be followed, including collection of information, decision-making and ensuring effective implementation of the investment decision.

\section{References:}

1. Burban O. V., Kryvoviaziuk I. V. (2018). The impact of environmental turbulence on investment decisions. Prychornomorski Ekonomichni Studii, 27(1), 29-33 [in Ukrainian].

2. Haidai, H. H. (2018). Investment potential as a basis for the formation of a set of strategic investment decisions. Ekonomika ta upravlinnia na transporti, 6, 106-112 [in Ukrainian].

3. Information and analytical portal of the AIC of Ukraine (2020). Retrieved from https://agro.me.gov.ua/ua/ investoram/monitoringstanu-apk/investiciyi/vprovadzhennya-investicijnih-proektiv [in Ukrainian].

4. Kozlovskyi, A. T. (2017). Practical aspects of using simulation modeling during the decision-making process on the implementation of investment projects at dairy enterprises. Innovatsiina ekonomika, 3-4, 232-237 [in Ukrainian]. 
Електронне наукове фахове видання з економічних наук «Modern Economics», №23 (2020), 174-179 https://modecon.mnau.edu.ua | ISSN 2521-6392

5. Kryvoviaziuk, I. V., Pakholchuk, A. I. (2013). The process of making business decisions and its impact on the efficiency of the enterprise. Efektyvna ekonomika, 4. Retrieved from http://www.economy.nayka.com.ua. [in Ukrainian].

6. Malykhina, O. M., Ishchenko, T. M., Savchuk, T. V. \& Petrenko, H. S. (2020). Features of business process indication in dynamic systems: prospects of investment decisions in modern construction development. Formuvannia rynkovykh vidnosyn v Ukraini, 1, 42-49 [in Ukrainian].

7. Marekha, I. S. (2013). Innovative approaches to substantiation of investment decisions in the field of agricultural land use on the basis of ecological and economic assessment of investment quality. Marketynh i menedzhment innovatsii, 4, 338-345[in Ukrainian].

8. Ostrovskaia, M. (2020). NIBULON has updated its truck fleet: for grain in white Mercedes cars. Yuzhnaia Pravda. Retrieved from http://www.up.mk.ua/mainpage/show_item/17318 [in Russian].

9. Potryvaieva, N. V., Pelypkanych, I. V. (2019). Prospects for updating the material and technical base of agricultural enterprises on the basis of innovations. Visnyk ahrarnoi nauky Prychornomorja, 2(102), 12-17. Retrieved from https://doi: 10.31521/2313-092X/2020 2(102)-2 [in Ukrainian].

10. Potryvaieva, N. V., Kozachenko, L. A. (2019). Leasing in the market of financial services of Ukraine: formation and tendencies of modern development. Rynok finansovyh posluh: pogliad u maibutnie: monohrafiia. Kyiv: FOP Yamchynsky O.V. [in Ukrainian].

11. Sirenko, N. M., Mikuliak, K. A. (2019). Investment component of agricultural sector development and its financial support in the market environment. Visnyk ahrarnoi nauky Prychornomorja, 3(103), 20-27. Retrieved from https://doi: 10.31521/2313-092X/2020-3(103)-3 [in Ukrainian].

12. Shebanin, V. S., Novikov, O. Y. \& Karpenko, M. D. (2020). The applicability of implementation of the irrigation in modern conditions. Visnyk ahrarnoi nauky Prychornomorja, 1(105), 4-10. Retrieved from https://doi: 10.31521/2313-092X/2020-1(105)-1 [in Ukrainian]

13. Sprynchuk, N. A., Voronetska, I. S., Korniichuk, H. V. \& Kravchuk, O. O. (2017). Investment decisions in agricultural enterprise development programs. Kormy i kormovyrobnytstvo, 84, 228-234 [in Ukrainian].

14. Yaremenko, O. F. Methods of making managerial decisions. Retrieved from https://msn.khnu.km.ua/mod /page/view.php?id=111388 [in Ukrainian].

15. Klochan, V. \& Klochan, I. (2018). Improvement of the mechanism of state regulation of investment in the innovative development of the agrarian sector. Baltic Journal of economic studies, 4(2), 99-105. https://doi.org/10.30525/2256-0742/2018-4-2-99-105 [in English].

Ця робота ліцензована Creative Commons Attribution 4.0 International License 